\title{
PEMETAAN WILAYAH BERDASARKAN PERTUMBUHAN EKONOMI DAN PERSENTASE PENDUDUK MISKIN KABUPATEN/KOTA DI PROVINSI SULAWESI UTARA
}

\author{
Adrianus Maabuat \\ Theodora M. Katiandagho \\ O. Esry H. Laoh
}

\begin{abstract}
The purpose of this research is to describe the mapping of North Sulawesi province based on the economic growth and the percentage of poverty in the regencies and the cities. This research was conducted over four months during January to April 2016. The data that used in this research is secondary data which gathered from Central Bureau Statistics. The analysis that used in this research is descriptive analysis which describe in table and quadrant based on number of economic growth and the percentage of poverty. The results of this research concluded that Sangihe and Talaud Islands Regency are the areas that have not experienced the changing over 2010 - 2014. The Regency of Sitaro Island in 2010-2014 succeeds to maintain the economic growth and the percentage of poverty above average. Kotamobagu and North Minahasa regency was able to sustain the economic growth above the average and poverty below the average during 2010-2014, regencies experienced the changing in quadrant position of economic growth and percentage of poverty during 2010-2014. "er"
\end{abstract}

Key words: mapping, the economic growth, the percentage of poverty, North Sulawesi province,

\begin{abstract}
ABSTRAK
Penelitian ini bertujuan untuk mendeskripsikan pemetaan wilayah Provinsi Sulawesi Utara berdasarkan pertumbuhan ekonomi dan persentase jumlah penduduk miskin di kabupaten dan kota. Penelitian ini dilaksanakan selama empat bulan, sejak bulan januari sampai pada bulan April 2016. Data yang digunakan dalam penelitian ini adalah data sekunder yaitu data yang diperoleh dari Badan Pusat Statistik Provinsi Sulawesi Utara. analisis yang digunakan dalam penelitian ini adalah analisis deskriptif yang dideskripsikan dalam bentuk table dan kuadran Berdasarkan hasil penelitian dapat disimpulkan bahwa Kabupaten Kep. Sangihe dan Kep. Talaud merupakan daerah yang tidak mengalami perubahan selama tahun 2010-2014 yaitu dengan pertumbuhan ekonomi dibawah ratarata dan persentase penduduk miskin di atas rata-rata, Kabupaten Sitaro pada tahun 2010-2014 berhasil meningkatkan pertumbuhan ekonomi di atas rata-rata namun persentase penduduk miskindi atas rata-rata. Kota Kotamobagu dan Kabupaten Minahasa Utara mampu mempertahankan pertumbuhan ekonomi di atas rata-rata dan persentase penduduk miskin di bawah rata-rata selama tahun 2010-2014, Kabupaten/kota lainnya mengalami perubahan posisi kuadran pertumbuhan ekonomi dan persentase penduduk miskin dari tahun 2010-2014.
\end{abstract}

Kata Kunci : Pemetaan, pertumbuhan ekonomi, persentase kemiskinan, Provinsi Sulawesi Utara

\section{PENDAHULUAN}

\section{Latar Belakang}

Proses

pertumbuhan

Pembangunan adalah suatu proses perubahan menuju ke arah yang lebih baik yakni mewujudkan masyarkat yang sejahtera. Pemerintah Indonesia menyadari bahwa pembangunan nasional merupakan salah satu proses upaya dalam mencapai tujuan masyarakat yang adil dan makmur. Proses 
pembangunan terjadi di semua aspek kehidupan masyarakat, baik aspek ekonomi, politik, sosial, maupun budaya.

Dibanyak daerah syarat utama bagi terciptanya penurunan kemiskinan adalah pertumbuhan ekonomi yang cepat. Pertumbuhan ekonomi adalah salah satu indikator penting dalam melakukan analisis tentang pembangunan ekonomi di Indonesia, pertumbuhan ekonomi menunjukan sejauhmana aktivitas perekonomian akan menghasilkan tambahan pendapatan masyarakat pada suatu periode tertentu. Salah satu tujuan dari pemerintah Indonesia memberikan otonomi daerah adalah untuk meningkatkan pertumbuhan ekonomi di daerah-daerah yang sulit di jangkau oleh pemerintah. Sekalipun demikian pertumbuhan ekonomi tidak cukup untuk mengentaskan kemiskinan tetapi biasanya pertumbuhan ekonomi merupakan sesuatu yang sangat dibutuhkan.

Pertumbuhan ekonomi diartikan sebagai perkembangan kegiatan dalam perekonomian yang menyebabkan barang dan jasa yang diproduksi dalam masyarakat bertambah dan kemakmuran masyarakat meningkat. Jadi pertumbuhan ekonomi mengukur prestasi dari perkembangan suatu perekonomian dari suatu periode ke periode lainnya, serta kemampuan suatu daerah untuk menghasilkan barang dan jasa akan meningkat. Dilihat dari sudut pandang ekonomi pertumbuhan ekonomi menimbulkan dua efek penting, yaitu kemakmuran atau taraf hidup meningkat dan penciptaan kesempatan kerja baru . Masalah kemiskinan memberikan dampak negatif, selain timbulnya masalahmasalah sosial, kemiskinan juga dapat mempengaruhi pembangunan ekonomi suatu negara. Jumlah penduduk miskin yang tinggi akan menyebabkan biaya yang harus dikeluarkan untuk melakukan pembangunan ekonomi menjadi lebih besar, sehingga secara tidak langsung akan menghambat pembangunan ekonomi.

Dalam hal ini pemerintah memiliki peran penting untuk menghilangkan kemiskinan, sebagaimana tujuan pembangunan nasional (Indonesia) yaitu mewujudkan masyarakat yang adil dan makmur, namun dapat diketahui bahwa sebenarnya kemiskinan itu belum dapat dihilangkan seutuhnya, tetapi yang lebih tepatnya adalah mengurangi terjadinya kemiskinan di setiap daerah. Permasalahan mengenai kemiskinan telah menjadi suatu masalah utama yang dihadapi berbagai daerah, namun sampai saat ini kemiskinan tidak dapat dihilangkan secara menyeluruh.

\section{Pengertian Pertumbuhan Ekonomi}

Pertumbuhan ekonomi adalah proses terjadinya kenaikan produk nasional bruto atau pendapatan nasional riil, dengan kata lain, perekonomian mengalami perkembangan jika terjadi pertumbuhan output riil. Pertumbuhan ekonomi merupakan target yag ingin dicapai oleh perekonomian dalam jangka panjang, dengan semaksimal mungkin konsisten dengan pertumbuhan ekonomi jangka pedek. Pertumbuhan ekonomi dapat menerangkan dan dapat mengukur prestasi perkembangan suatu perekonomian.

\section{Konsep Kemiskinan}

Kemiskinan adalah keadaan dimana terjadi ketidakmampuan untuk memenuhi kebutuhan dasar seperti makanan, pakaian, tempat berlindung, pendidikan, dan kesehatan. Makmum (2003) mengaakan bahwa Kemiskinan dipahami dalam berbagai cara, pemahaman utamanya mencakup: (1). Gambaran kekurangan materi, yang biasanya mencakup kebutuhan pangan sehari-hari, sandang, perumahan, dan pelayanan kesehatan. Kemiskinan dalam arti ini dipahami sebagai situasi kelangkaan barang-barang dan pelayanan dasar. (2) Gambaran tentang kebutuhan sosial, termasuk keterkucilan sosial, ketergantungan, dan ketidakmampuan untuk berpartisipasi dalam masyarakat. Hal ini termasuk pendidikan dan informasi. Keterkucilan sosial biasanya dibedakan dari kemiskinan, karena hal ini mencakup masalah-masalah politik dan moral, dan tidak dibatasi pada bidang ekonomi. (3). Gambaran tentang kurangnya penghasilan dan kekayaan yang memadai. Makna "memadai" di sini sangat berbedabeda melintasi bagian-bagian politik dan ekonomi di seluruh dunia. Gambaran tentang ini dapat diatasi dengan mencari objek penghasilan di luar profesi secara halal. Perkecualian apabila institusi tempatnya bekerja melarang. 


\section{Hubungan Pertumbuhan Ekonomi Dan Kemiskinan}

Kemiskinan telah membuat pengangguran semakin bertambah banyak, inflasi naik, dan pertumbuhan ekonomi melambat. Tetapi pertumbuhan ekonomi yang tinggi merupakan gambaran terhadap kesejahteraan faktor produksi yang turut serta menciptakan kesejahteraan tersebut, artinya semakin tinggi laju pertumbuhan ekonomi maka semakin tinggi pula produktifitas faktor produksi dan semakin tinggi pula upah yang di terima oleh para pekerja. Pertumbuhan ekonomi memang merupakan syarat keharusan untuk mengurangi kemiskinan tetapi itu belum cukup. Syarat kecukupannya ialah, misalnya: laju inflasi serta lau populasi penduduk yang terkendali, indistrialisasi pertanian/perdesaan yang tepat, akumulasi modal manusia yang relatif cepat, harus dipenuhi pula (Hilmawan, 2012.). Karena itu pertumbuhan ekonomi sangat berkaitan dengan masalah kemiskinan, karena pertumbuhan ekonomi dikatakan meningkat apabila kemiskinan ditanggulangi secara efektif.

\section{Rumusan Masalah}

Berdasarkan pada latar belakang yang telah diuraikan, maka yang menjadi permasalahan adalah bagaiman pemetaan wilayah Provinsi Sulawesi Utara berdasarkan pertumbuhan ekonomi dan persentase penduduk miskin di kabupaten dan kota ?

\section{Tujuan Penelitian}

Penelitian ini bertujuan untuk mendeskripsikan pemetaan wilayah Provinsi Sulawesi Utara berdasarkan pertumbuhan ekonomi dan persentase penduduk miskin di kabupaten dan kota.

\section{Manfaat Penelitian}

Adapun manfaat penulisan penelitian ini diharapkan dapat :

1. Memberikan wawasan bagi penulis mengenai hubungan pertumbuhan eknomi dan tingkat kemiskinan
2. Dapat menjadi bahan pertimbangan atau dikembangkan lebih lanjut, serta refernsi terhadap penelitian sejenis.

\section{METODOLOGI PENELITIAN}

\section{Waktu Dan Tempat Penelitian}

Penelitian ini bertempat di Provinsi Sulawesi Utara yang terdiri dari 15 kabupaten dan kota. Penelitian ini dilaksanakan pada bulan Januari sampai dengan bulan April Tahun 2016.

\section{Jenis Dan Sumber Data}

Data yang digunakan dalam penelitian ini adalah data sekunder yakni data time series. Data sekunder biasanya telah dikumpulkan oleh lembaga pengumpul data dan dipublikasikan kepada masyarakat pengguna data (Sarwono, 2006)

Data dalam penelitian ini diperoleh dari Badan Pusat Statistik Provinsi Sulawesi Utara, literatur-literatur lain yang membahas mengenai materi penelitian yang bersangkutan.

\section{Konsepsi Pengukuran Variabel}

Adapun Variabel yang diteliti dan diukur dalam penelitian ini adalah :

1. Pertumbuhan Ekonomi kabupaten/kota di Provinsi Sulawesi Utara dalam (\%), yaitu laju pertumbuhan Produk Domestik Regional Bruto Kabupaten/Kota Provinsi Sulawesi Utara selama Tahun 2010-2014.

2. Penduduk Miskin di Sulawesi Utara selama tahun 2010-2014 dalam (\%).

\section{Analisis Data}

Analisis data yang digunakan dalam penelitian ini adalah analisis deskriptif yang disajikan/deskripsikan dalam bentuk tabel dan bentuk kuadran berdasarkan angka persentase pertumbuhan ekonomi dan penduduk miskin untuk melihat pemetaan wilayah berdasarkan pertumbuhan ekonomi dan persentase jumlah penduduk miskin dari tahun 2010-2014. 


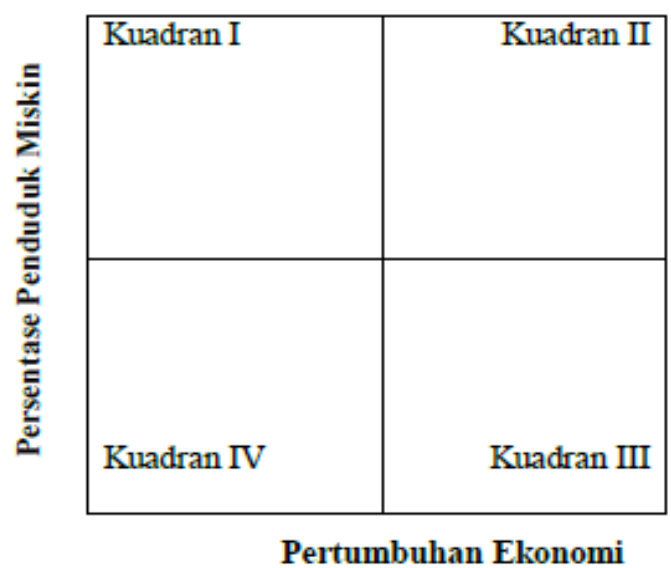

Gambar 1. Persentase Penduduk Miskin dan Pertumbuhan Ekonomi

Keterangan penempatan kuadran :

Kuadran I ditempati oleh kabupaten/kota dengan nilai pertumbuhan ekonomi di bawah rata-rata dan persentase penduduk miskin di atas rata-rata.

Kuadran II ditempati oleh kabupaten/kota dengan nilai pertumbuhan ekonomi di atas rata-rata dan persentase penduduk miskin di atas rata-rata.

Kuadran III ditempati oleh kabupaten/kota dengan nilai pertumbuhan ekonomi di di atas rata-rata dan persentase penduduk miskin di bawah ratarata.

Kuadran IV ditempati oleh kabupaten/kota dengan nilai pertumbuhan ekonomi di bawah rata-rata dan persentase penduduk miskin di bawah ratarata.

\section{HASIL DAN PEMBAHASAN}

\section{Gambaran Umum Lokasi Penelitian}

Provinsi Sulawesi Utara adalah wilayah di ujung utara Pulau Sulawesi, berbatasan langsung dengan Negara Filipina. Provinsi Sulawesi Utara yang beribukota di Manado dengan batas-batas wilayah sebagai berikut :

1. Sebelah Utara : Republik Filipina dan Laut Pasifik

2. Sebelah Timur : Laut Maluku

3. Sebelah Selatan : Teluk Tomini

4. Sebalah Barat : Provinsi Gorontalo
Pemetaan Wilayah Berdasarkan Pertumbuhan Ekonomi Dan Persentase Jumlah Penduduk Miskin Kabupaten/Kota Di Provinsi Sulawesi Utara Tahun 2010-2014 Pemataan wilayah berdasarkan pertumbuhan ekonomi dan persentase jumlah penduduk miskin di Provinsi Sulawesi Utara dapat dilihat dari pola sebaran pada masingmasing kabupaten/kota dengan menggunakan data pertumbuhan ekonomi dan persentase penduduk miskin pada masing-masing kabupaten/kota yang diolah dan kemudian digambarkan menggunakan analisis kuadran. Analisis kuadran ini menggunakan dua perbandingan indikator yang dibagi empat wilayah plot berdasarkan nilai rata-rata pertumbuhan ekonomi dan persentase penduduk miskin.

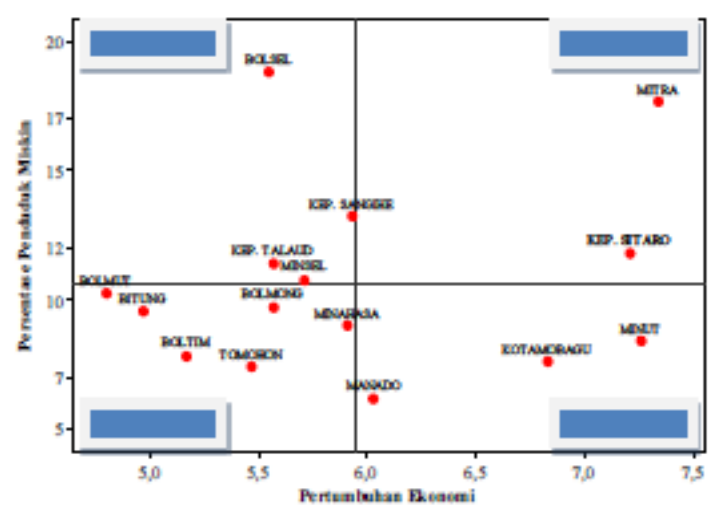

Gambar 2. Persentase Penduduk Miskin

Sumber : BPS Sulut (Data Diolah)

Pada tahun 2010 Kabupaten Bolaang Mongondow Selatan, Kep. Sangihe, Kep. Talaud dan Minahasa Selatan menempati kuadran I yang termasuk kategori dengan wilayah pertumbuhan ekonomi di bawah ratarata Provinsi Sulawesi Utara dan persentase penduduk miskin di atas rata-rata Provinsi Sulawesi Utara. Kondisi ini menunjukan bahwa tantangan yang harus di atasi oleh pemerintah daerah adalah menjaga efektivitas dan efisiensi kebijakan dan program pengurangan kemiskinan, dan secara bersama mendorong percepatan pembangunan ekonomi dengan prioritas sektor atau kegiatan ekonomi yang mempunyai potensi perkembangan seperti pertanian, perkebunan, kelautan, perikanan serta perdagangan dan jasa.

Kuadran II menggambarkan pertumbuhan ekonomi yang berada di atas rata- 
rata dan persentase penduduk miskin di atas rata-rata Provinsi Sulawesi Utara. Wilayah ini di tempati oleh dua kabupaten, yaitu Kabupaten Minahasa Tenggara dan Kabupaten Kep. Sitaro. Kondisi ini menunjukan bahwa pertumbuhan ekonomi yang tinggi belum bisa mengatasi atau berdampak pada pengurangan jumlah persentase penduduk miskin secara efektiv, kususnya pada kedua daerah tersebut. Hal ini menjadi perhatian bagi pemerintah untuk tidak hanya memperhatikan pembangunan ekonomi saja tetapi juga bagaimana upaya pemerintah dalam program pengurangan kemiskinan. Sedangkan pada Kuadran III yaitu wilayah kuadran yang paling ideal hanya di tempati oleh tiga kabupaten/kota saja, yaitu Kota Manado, Kota Kotamobagu dan Kabupaten Minahasa Utara, di mana kondisi wilayah pertumbuhan ekonomi di atas rata-rata namun persentase penduduk miskin di bawah rata-rata Provinsi Sulawesi Utara. Hal ini menunjukan bahwa pertumbuhan ekonomi yang terjadi pada tiga kabupaten/kota tersebut dapat mendorong pengurangan kemiskinan secara lebih cepat. Dengan kondisi ini, pemerintah harus menjaga laju pertumbuhan ekonomi dengan tetap meningkatkan upaya pengurangan kemiskinan.

Berdasarkan gambar enam, dilihat dari pola penyebaran kabupaten/kota berdasarkan pertumbuhan ekonomi dan persentase penduduk miskin, penyebaran di dominasi pada kudran IV yang di tempati oleh enam kabupaten/kota, yaitu Kota Bitung, Kebupaten Bolaang Mongondow, Kabupaten Bolaang Mongondow Utara, Kabupaten Bolaang Mongondow Timur, Kota Tomohon dan Kabupaten Minahasa dengan wilayah kuadran pertumbuhan ekonomi di bawah rata-rata dan persentase penduduk miskin di bawah rata-rata pula Provinsi sulawesi Utara. Kondisi ini menggambarkan bahwa pemerintah harus bekerja keras untuk mondorong percepatan pembangunan ekonomi serta lebih meningkatkan lagi dalam program penanggulangan kemiskinan.

Dapat dilihat bahwa tahun 2014 terjadi perpindahan posisi kuadran bagi beberapa kabupaten/kota, seperti Kabupaten Minahasa Tenggara dan Minahasa Selatan yang sejak tahun 2011-2013 berada pada wilayah kuadran I berhasil meningkatkan pertumbuhan ekonominya sehingga menempati wilayah kuadran II, artinya kedua kabupaten tersebut memiliki kondisi dimana pertumbuhan ekonomi di atas rata-rata namun persentase penduduk miskin tetap berada di atas rata-rata pula. Sementara itu Kabupaten Kep. Sangihe dan Kabupaten Talaud masih berada pada wilayah kuadran I sejak tahun 2010 dan juga Kabupaten Bolaang Mongondow Selatan, Kabupaten Bolaang Mongondow Utara dan Kabupaten Kep. Sitaro masih menempati kuadran II.

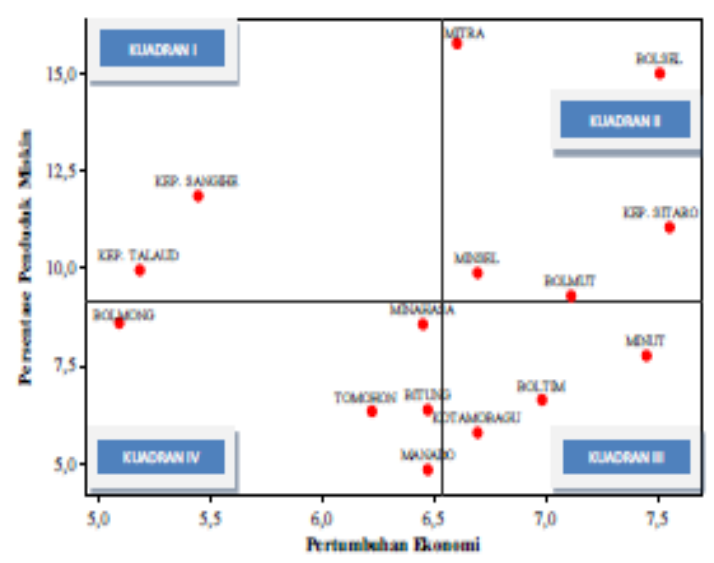

Gambar 3. Persentase Penduduk Miskin

Sumber : BPS Sulut (Data Diolah)

Wilayah kuadran III ditempati oleh tiga kabupaten/kota yaitu Kota Kotamobagu, Kabupaten Minahasa Utara dan Kabupaten Bolaang Mongondow Timur, artinya ketiga kobupaten/kota ini memiliki kondisi yang ideal yaitu berada pada kondisi pertumbuhan ekonomi di atas rata-rata dan persentase penduduk miskin dibawah rata-rata, disamping itu Kota Kotamobagu dan Kabupaten Minahasa Utara berhasil mempertahankan prestasinya sejak Tahun 2010 sampai dengan tahun 2014. Sedangkan Kota Manado yang sejak Tahun 2010 sampai tahun 2013 berada pada wilayah kuadran III, sekarang mengalami penurunan pada pertumbuhan ekonomi sehingga Kota Manado bergeser pada kuadran IV, namun sekalipun demikian Kota Manado tetap saja memiliki persentase penduduk miskin yang paling rendah dibandingkan dengan kabupaten/kota yang lain. Selain Kota Manado Kuadran IV di tempati oleh Kabupaten Minahasa, Kota Bitung, Kota Tomohon dan Kabupaten Bolaang Mongondow.

Tahun 2014 Badan Pusat Statistik mencatat gini rasio Provinsi Sulawesi Utara 
menunjukan posisi pemerataan distribusi pendapatan yang sedang dengan nilai 0,42 . Berdasarkan pengelompokan pertumbuhan ekonomi dan Persentase penduduk miskin kabupaten/kota di Provinsi Sulawesi Utara yang disajikan melalui tabel selama tahun 2010 -2014, menunjukan bahwa Kabupaten Kep. Sangihe dan Kabupaten Kep. Talaud merupakan daerah yang tidak mengalami perubahan posisi kuadran, dimana dapat dilihat dari tahun 2010 - 2014 kedua kabupaten/kota tesebut berada pada kuadran I. Badan Pusat Statistik Provinsi Sulawesi utara Mencatatat bahwa pengeluaran per kapita kabupaten Kep. Talaud di dominasi oleh 20,49 persen jumlah penduduk dengan pengeluaran Rp.300.000 - Rp. 500.000 dan Kep. Sangihe oleh 19,27 persen jumlah penduduk dengan pengeluaran Rp. $200.000-$ Rp.300.000 hal ini menggambarkan bahwa pada kedua kabupaten tersebut masih banyak penduduk yang memiliki dayabeli yang rendah di samping itu pada kuadran II terdapat Kabupaten Kep. Sitaro yang tidak berubah dari tahun 2010 - 2014, sekalipun kabupaten Kep. Sitaro memiliki pertumbuhan ekonomi yag tinggi namun masih banyak masyarakat yang memiliki dayabeli yang rendah, hal ini dapat dilihat bahwa sebagian besar penduduk kabupaten Kep. Sitaro memiliki pengeluaran yang hanya $\mathrm{Rp}$. 300.000 - 750.000, sedangkan berdasarkan PDRB per kapita, daerah kabupaten Kep. Sitaro memiliki rata-rata pendaptan 1,46 juta per bulan, kondisi ini menggambarkan bahwa pertumbuhan ekonomi yang di alami kabupaten tersebut tidak dapat dirasakan oleh semua masyarakat melainkan hanya golongan tertentu saja. Pada kuadran III ada Kota Kotamobagu dan Kabupaten Minahasa Utara yang berhasil mempertahankan prestasinya dengan tidak mengalami perubahan posisi kuadran sejak tahun 2010-2014 dan yang terakhir ada Kabupaten Bolaang Mongondow yang selama tahun 2010-2012 berada pada kuadran IV kemudian berhasil meningkatkan pertumbuhan ekonomi dan bergeser pada kuadran III pada tahun 2013, namun pada tahun 2014 kebupaten tersebut mengalami penurunan pada pertumbuhan ekonomi sehingga kembali menempati kuadran IV. Kabupaten Bolaang Mongondow Utara pada tahun 2013 dan tahun 2014 mengalami peningkatan pada pertumbuhan ekonomi namun disamping itu persentase penduduk miskin juga mengalami peningkatan, hal ini dikarenkan pertumbuhan ekonomi yang tidak dirasakan oleh semua masyarakat atau pun berdampak positif terhadap penurunan tingkat kemiskinan pada daerah tersebut, hal ini dapat dilihat bahwa rata-rata PDRB per kapita Kabupaten Bolaang Mongondow tahun 2014 adalah 1,39 juta per bulan sedangkan pengeluaran per kapita kabupaten Bolaang Mongondow Utara di dominasi oleh 27,49 persen penduduk dengan pengeluaran Rp. 200.000 - Rp. 300.000 per bulan, pada kondisi ini menggambarkan daerah tersebut memiliki dayabeli masyarakat yang relatif rendah.

\section{KESIMPULAN DAN SARAN}

\section{Kesimpulan}

Berdasarkan dengan data yang diperoleh dan diolah maka dapat disimpulkan bahwa :

1. Kabupaten Kep. Sangihe dan Kabupaten Kep. Talaud merupakan daerah yang tidak mengalami perubahan selama tahun 20102014, yaitu pertumbuhan ekonomi di bawah rata-rata Provinsi Sulawesi Utara dan persentase penduduk miskin di atas rata-rata Provinsi Sulawesi Utara.

2. Kabupaten Sitaro pada tahun 2010-2014 berhasil mempertahankan pertumbuhan ekonomi di atas rata-rata Provinsi Sulawesi Utara tetapi belum berhasil dalam pengurangan kemiskinan yang tetap berada di atas rata-rata Provinsi Sulawesi Utara.

3. Kota Kotamobagu dan Kabupaten Minahasa Utara mampu mempertahankan pertumbuhan ekonomi di atas rata-rata dan persentase penduduk miskin di bawah ratarata Provinsi Sulawesi Utara selama tahun 2010-2014. 
4. Kabupaten/Kota lainnya yaitu, Kabupaten Bolaang Mongondow, Kabupaten Minahasa, Kabupaten Minahasa Selatan, Kabupaten Bolaang Mongondow Utara, Kabupaten Minahasa Tenggara, Kabupaten Bolaang Mongondow Selatan, Kabupaten Bolaang Mongondow Timur, Kota Manado, Kota Bitung dan Kota Tomohon merupakan daerah-daerah yang mengalami perubahan posisi kuadran pertumbuhan ekonomi dan persentase penduduk miskin Provinsi Sulawesi Utara dari tahun 20102014.

\section{Saran}

Hasil penelitian yang disajikan menunjukan tidak semua daerah yang mengalami peningkatan pertumbuhan ekonomi dapat menurunkan persentase penduduk miskin. Daerah yang mengalami pertumbuhan ekonomi di bawah rata-rata Provinsi Sulawesi Utara menjadi tantangan bagi pemerintah untuk lebih meningkatkan produktivitas sektor atau kegiatan ekonomi, terutama pada sektor atau kegiatan ekonomi yang mampu menyerap tenaga kerja lebih banyak. Bersamaan dengan itu pemerintah harus mengoptimalkan program penanggulangan kemiskinan terutama pada daerah-daerah yang berada pada persentase penduduk miskin di atas rata-rata Provinsi Sulawesi Utara.

\section{DAFTAR PUSTAKA}

Badan Perencanaan Pembangunan Daerah. 2014. Perkembagan Pembangunan Provinsi Sulawesi Utara 2014. Seri Analisis Pembangunan Daerah.

Badan Perencanaan Pembangunan Nasional. 2013. Simpadu-pk.bappenas.go.id/ ajax_datamart/download_file/7. Di akses pada tanggal 28 Januari 2016.

Badan Pusat Statistik, 2015. www.bps.go.id. Di akses pada tanggal 25 Oktober 2015.
Badrudin, R. 2012. Ekonomika Otonomi Daerah. Penerbit UPP STIM YKPN.

Hilmawan, R. 2012. Perekonomian Indonesia: Beberapa Telaah Kontemporer. Penerbit LPFE Universitas Borneo Tarakan.

Kuncoro, M. 2015. Indikator Ekonomi. Penerbit Erlangga.

Kuznet, 2009.Membuka Cakrawala Ekonomi. Penerbit Pusat Perbukuan Depertemen Pendidikan Nasional.

Maipita, I. 2014. Mengukur Kemiskinan dan Distribusi Pendapatan. Penerbit UPP STIM YKPM.

Makmum. 2003. Gambaran Kemiskinan dan Action Plan Penanganannya." Kajian Ekonomi dan Keuangan, Vol. 7, No. 2.

Panji, I. 2015. Peranan Pertumbuhan Ekonomi Terhadap Tingkat Kemiskinan di Provinsi Bali. Skripsi Fakultas Ekonomi dan Bisnis, Universitas Udayana Denpasar.

Rahardja, P. 2005.Teori Flonomi Makro Edisi Ketiga. ] rbit Fakultas Ekonomi Universitas Indonesia.

Ricardo, D. 2013. Perekonomian Indonesia. Penerbit Galia Indonesia.

Rofiq, A. 2014. Pertumbuhan Ekonomi dan Kemiskinan. Penerbit Republika Penerbit.

Sarwono, J. 2006. Metode Penelitian Kuantitatif dan Kualitatis. Penerbit Graha Ilmu.

Smith, A. 2007. Ekonomi dan Akuntansi: Membina Kompetensi Ekonomi. Penerbit PT Grafindo Media Pratama. 
Sumbayak, D. 2015. Pengaruh Pertumbuhan Ekonomi Terhadap Tingkat Kemiskinan di Provinsi Sumatera Utara. Research Universitas Indonesia, Fakultas Ekonomi

Tambunan, T. 2013. Perekonomian Indonesia. Penerbit Galia Indonesia.
Yacoub, Y. 2012. Pengaruh Pengangguran Terhadap Tingkat Kemiskinan Kabupaten Kota di Provinsi Kalimantan Barat. Jurnal Volume 8, No. 3. 